\title{
"Wat sê jy?" The linguistic characteristics of Afrikaans on IRC
}

Kate M. van Gass

Department of General Linguistics, Stellenbosch University, Private Bag X1, Matieland 7600. E-mail: katevg@sun.ac.za

\section{Introduction}

It is widely accepted that the development and spread of computer-mediated communication (CMC) has had visible effects on language and how it is used, and will continue to shape our language use. To date, research on CMC has focused mainly on English; however, "if we are to understand truly how the Internet might shape our language, then it is essential that we seek to understand how different varieties of language are used on the Internet" (Paolillo 1999). One way to achieve this aim is to undertake research within populations communicating online in languages other than English. Some examples of this approach are studies of the linguistic and interactional properties of Japanese CMC (Nishimura 2003); of Swedish chat communication (Hård af Segerstad 2000); and of Gulf Arabic in Instant Messaging (Palfreyman and al Khali 2003). As Danet and Herring (2003) point out, there are many questions raised by the "multilingual internet", such as "what are the distinctive features of chat in languages other than English?" and "what are the effects of the English language and global 'netspeak' (Crystal 2001) on CMC in these languages?"

In this paper, the linguistic and interactional characteristics of Afrikaans, as used on Internet Relay Chat (IRC) and DC++ (a file sharing application that allows for synchronous 
chatting), are examined. Firstly, a brief characterisation of IRC and DC++ is given. This is followed by a discussion of the data capturing methodology. Finally, the data are analysed with the intention of identifying the characteristics of the variety or varieties of Afrikaans used in CMC. These characteristics are compared to the characteristics of spoken and (traditional) written forms of Afrikaans and to the already well-researched characteristics of the varieties of English used in CMC, such as the discursive properties of IRC communication as identified by Werry (1996) and the common features of digital writing as identified by Danet (2000:17).

\section{Internet Relay Chat}

Internet Relay Chat (IRC) is a multi-user synchronous communication system developed in 1988 by Jarkko Oikarinen (Reid 1991). Accessed through client programs such as ircII and mIRC, it is one of the oldest and most popular systems of CMC (Rintel, Mulholland and Pittam 2001). Its popularity seems to stem mainly from the fact that, although it is a written (or rather, typed) medium, the real-time, synchronous transmission of messages between users makes IRC interaction feel similar to face-to-face conversation (Reid 1991; Newhagen and Rafaeli 1996; Werry 1996).

Conversations on IRC take place inside channels, which are prefixed by a hash symbol. Channels are created or joined by users issuing a command to the IRC program to join a channel. Channels can have any name, but generally the name of the channel indicates the nature of the conversation being carried on within it (Reid 1991). Figure 1 shows a list of some channel names as they appear to an IRC user. The left hand column displays the name of the channel, the middle column displays how many people are currently on the channel, and the right hand column indicates the theme of the channel or the current topic of conversation. 
Figure 1: Sample list of IRC channels

\begin{tabular}{|c|c|c|}
\hline \#sun & 22 & CronTaB \& Exil Season 2 Trailer 3 at http://irc.sun.ac.za/ \\
\hline \#eros & 14 & CHECK IT---> http://wuw -worldometers.info/ \\
\hline \#trivia & 6 & \\
\hline \#YAC & 5 & \#yac yacity yac \\
\hline $\begin{array}{l}\text { \#uisuang } \\
\text { \#oners }\end{array}$ & $\begin{array}{l}3 \\
2\end{array}$ & "Bekstil!" - Jarod, circa 2005 \\
\hline
\end{tabular}

Interaction on IRC is largely anonymous. A user selects a nickname, or "nick", to identify him- or herself. Nicks vary from conventional first names, such as $<$ Billy $>$ or $<$ Sean $>$, to unusual and imaginative pseudonyms, such as $<$ V_i_P_e_R $>$ and $<\wedge$ Ange $\| \wedge][$ ce $>$. When nicks appear in the chat logs, they are always enclosed by triangular brackets $(<>)$. Although a user's e-mail address and his or her real name is, by default, available to other users, this information can be hidden or changed at any time. IRC commands, prefaced by a slash, allow users to perform specific functions on IRC, such as joining a channel or changing a nick. ${ }^{1}$

$\mathrm{DC}++$, the other CMC system used in this study, is a file sharing application, which also supports synchronous "chatting". Although its primary function is file sharing, this program is used successfully as an online communication tool, and as such has much in common with IRC, despite not necessarily supporting all the possible commands of IRC. DC++ does not consist of channels, but rather of public and private hubs, hosted by individual servers and accessed by users via a local network. Users communicate via DC++ in the same way as they communicate on IRC, as can be seen in Figures 2 and 3. 
Figure 2: Screenshot of mIRC (IRC client program)

[15:43] 〈k8tè en bonop kan jy videos dounloadt

[15:43] 〈Ho1fMage〉 jip

[15:43] 〈WolfMage〉 jip
$[15: 43]$ 〈WolfMage〉 watter kh is jy?

[15:43] 〈Wolfhage〉 hehe

[15:44] 〈k8tE〉 wkwaliteit

[15:44] 〈WolfMage〉 wat's jou naan op de?

[15:44]〈k8tE〉 dunno

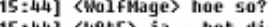

[15:44] 〈hotE> nie op die nick geerf

[15:45] 〈xact) moet dit nie oonblik nie

[15:45] 〈WolfMage> tegniers jas no xact

[15:45] 〈0ata_Werk> nee man 5005 dit nou staan

$[15: 45]$ <0at)

[15:45] <xact> nee

$[15: 45]\langle 0$ ata Werk

[15:45] <xact $>$ dis veight

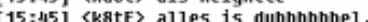

[15:46]* 0rages a

[16:05] * Quits: v1annie (quit: of all the things I've 1ost, I

alss $n$ ald the most?:0)

aiss my wind the most

[16:13] * Joins: Agnus

[16:18] 〈MolfMage〉 v1annie, julle al k1aar terug?

[16:18] 〈WolfMage〉 hoe was kopie?

$[16: 19]$ * Mo]fMage begin stallig nar. seker aanstap na keffie toe.

[16:29] (ngeus) cheers aense

[16:23] * Joins:- Jessicanatbit

$[16: 24]\langle u 1 a n n i e\rangle$ nee

[16:24]〈ulamnie〉 ek gaan nie saan nie

$[16: 24]\langle v 1 a n n i e\rangle$ p en 'n ander ou gaan

$[16: 24]$ 〈ulamie> ek noet verk doen :/

[16:25] * Quits: Aqnus (Quit: Today is a good day to chat.)

$[16: 29]$ 〈ata_Werk〉 dann

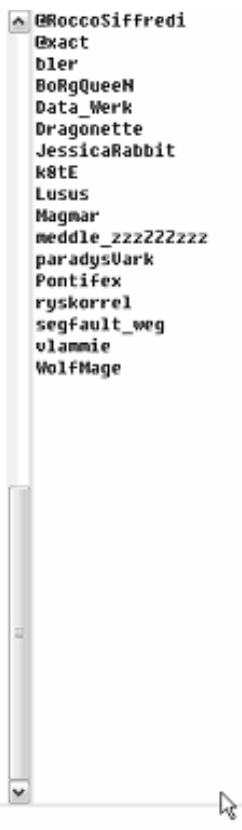

Figure 3: Screenshot of DC++
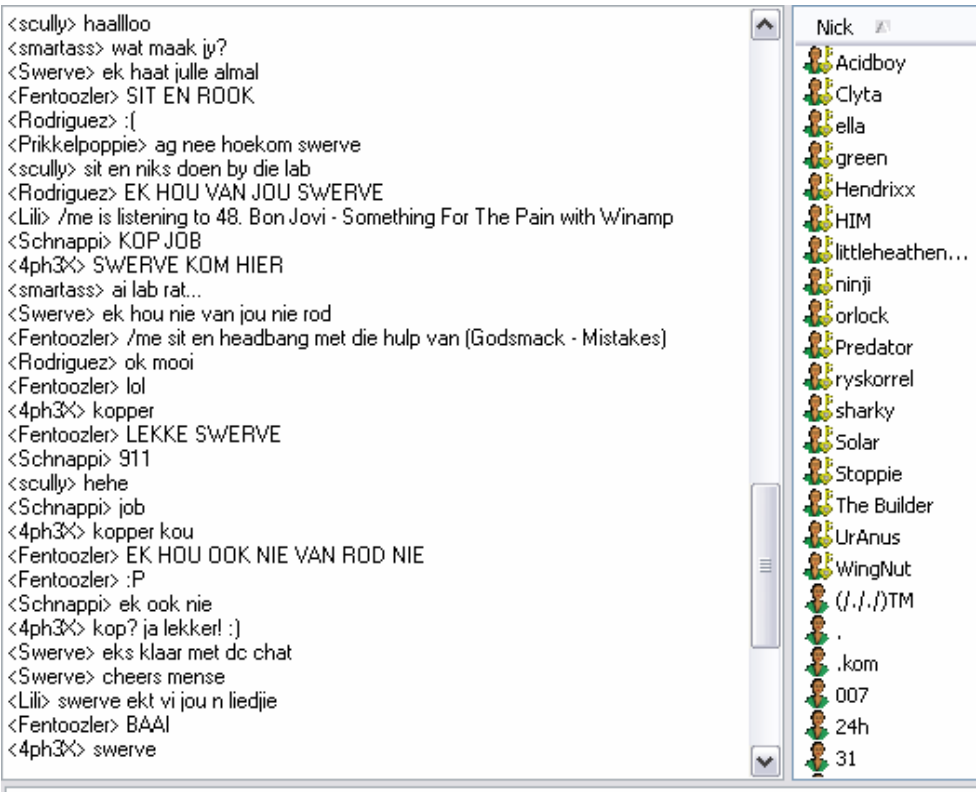

\section{Methodology}

Both IRC and DC++ allow users to record sessions in the form of a "log" which saves all the on-screen activity to a text file. The data used in this study were collected at various 
times from January to April 2005 on two channels (\#sun and \#eros) on sun.irc.ac.za (the Stellenbosch University IRC server) and on various DC++ public hubs, accessible through Stellenbosch University's intranet. As the data collected from these two environments are, for our intents and purposes, the same, the term "IRC" will be used from this point on to refer to both IRC and DC++.

The users of these systems are presumed to be students studying at Stellenbosch University, with access to the intranet/internet from their hostel rooms on the Stellenbosch and Tygerberg campuses or, in the case of some postgraduate students, from offices located on either of these campuses. As such they are all assumed to be bilingual in Afrikaans and English, as these are the two languages used by the University for lecturing purposes.

IRC is by definition in the public domain; anyone with a computer and access to a server can log on. It is also possible for all users to make logs of their interactions. On IRC, there is a distinction between private and public channels (or hubs in the case of DC++), and a channel operator is able to make a channel private at any time, excluding it from the public space. Users are also able to have private conversations, separate from the main discussion, which are not seen or logged by any other user. These considerations mean that IRC logs should be viewed as public, and therefore available for use in research.

As regards anonymity, users on IRC make use of nicks, by which they in fact conceal their real identity. There is no ethical need therefore to disguise the identity of the users, as this has already been achieved by the users themselves (Danet, Reudenberg-Wright and Rosenbaum-Tamari 1997).

\section{Characteristics of Afrikaans on IRC}

\subsection{Differences between CMC and spoken and traditional written language}

One of the major factors that determines the linguistic nature of CMC discourse is synchronicity (Herring 2001). The features that characterise this discourse on, for example, IRC have led researchers to posit that CMC occupies a position on a continuum between 
spoken and written language (Murray 1988; Baron 1998, 2000). The data examined in this study suggest that this also holds for Afrikaans CMC.

Traditionally, writing has been seen as slow, deliberate, and able to be edited, while speech is unplanned and spontaneous. According to Chafe (1985:105), writing has a detached quality that contrasts with the involvement of spoken language, due to the fact that speaking generally takes place in an environment of social interaction, while writing is a "lonely activity". This opposition of involvement versus detachment is the result of the fact that speakers are usually face-to-face with their interlocutors whereas writers are isolated both spatially and temporally from their audience (Chafe 1985:116). The nature of CMC, especially as it occurs on IRC, is such that, despite its use of a written medium, it takes place in an environment of social interaction, and so displays the involvement that characterises typical spoken language, rather than the detachment of traditional written language. The following two examples of Afrikaans $\mathrm{CMC}^{2}$ show both ego involvement, that is the involvement of the speaker with himself, and involvement with the hearer. The speaker, <bler>, addresses the hearer twice in the first example using the second-person pronoun $j y$, and he uses the first person pronoun $e k$ to refer to himself. In the second example, the speaker addresses the hearer by name (<segfault $>$ ).

$<$ bler $>$ niks maak jou so vrolik soos missing memory nie $<$ bler $>$;) $<$ bler $>$ maar jy sal dit nog agter kom.

$<$ bler $>$ o wag, ek het vergeet, jy's mos een van daai slim ing ouens

(2) $\quad<$ bler $>$ hmm

$<$ bler $>$ hoekom nie segfault?

Chafe (1985:112) also identifies other differences between written and spoken language. Typical features of spoken language include those that have to do with the rapid rate of information flow, such as flow-monitoring devices and disfluencies. As we see from the following examples, communication on IRC also displays these features: flow-monitoring devices, the English words ok, say, and right and the Afrikaans words wel and ja, are used to control the flow of information "like sluice gates in the stream of speech" (Chafe 
1985:112). Examples (5)-(7) illustrate the occurrence of disfluencies, such as afterthoughts, repetitions, corrections and fumblings, which are similar to those that occur in spoken language.

(3) $\quad<$ JessicaRabbit> ok WildBerry, my pc se private details nou almal neergeskryf ;p $<$ xact $>$ as opposed to, say, public details?

(4) <JessicaRabbit> wel sy het omtrent 10gig spasie en dis hoeveel my musiek is $<$ JessicaRabbit $>$ ja, ek sal net eers seker maak sy't als opgekry $<$ WildBerry $>$ right

(5) <xact $>$ of is die afwesigheid juis weens klasse, dink julle?

$<$ WildBerry $>$ um

$<$ WildBerry $>$ komitee sou ek dink

(6) <WildBerry $>\mathbf{h m m m}$ ek begin beter voel.. this is good :)

(7) $\quad<$ Delltree $>$ So... Voor ons nou te serious en diep raak...

$<$ Delltree $>$ Oh ok...

$<$ Delltree $>$ Flaws

$<$ Delltree $>$ Laat ek dink

$<$ Delltree $>$ Ek trust nie maklik ander nie...

Chafe (1985:106) maintains that some of the differences between written and spoken language can only be understood with reference to the notion of 'idea units'. The term "idea units" refers to the series of spurts in which spontaneous, unplanned language is produced. Although most written texts do appear to show idea units, these units tend to be significantly longer and more complex than those of spoken language. When we examine the Afrikaans CMC data, it is clear that most of the communication exhibits the short, independent idea units that characterise spoken language, as illustrated in examples (8)-(9).

$$
\begin{aligned}
& <\text { Agnus }>\text { ek eet choclate } \\
& <\text { Data_Hoare }>\text { lekker } \\
& <\text { Data_Hoare }>\text { ek is bly } \\
& <\text { Data_Hoare }>\text { chocolate is mos jou kos }
\end{aligned}
$$


(9) $\quad<$ Mfg $>$ Ek is sterkteleer ook darem net op my gat deur...

$<$ BoRgQueeN $>$ ek ook

$<$ BoRgQueeN $>$ die vak haunt my

$<$ BoRgQueeN $>$ ek kannie ontslae daarvan raak nie

$<$ BoRgQueeN $>$ dis al wat ek demi

\subsection{Organisation of conversational sequences and exchange structures}

One feature of IRC discourse, however, that distinguishes it from both spoken and traditional written language is the organisation of conversational sequences and exchange structures (Werry 1996:51). The technical specifications of IRC mean that a message is displayed in the chronological order in which it is received by the server. The nature of the internet is such that some users' connections will be slower than those of otehrs, and this could then lead to the distortion of order in message transmission (Rintel and Pittam 1997:531). Users' contributions to different conversations also take place simultaneously, and so threads of different conversations are juxtaposed and different topics become interwoven. The following example shows this kind of sequencing in IRC communication, and provides evidence that this feature is characteristic of Afrikaans CMC.

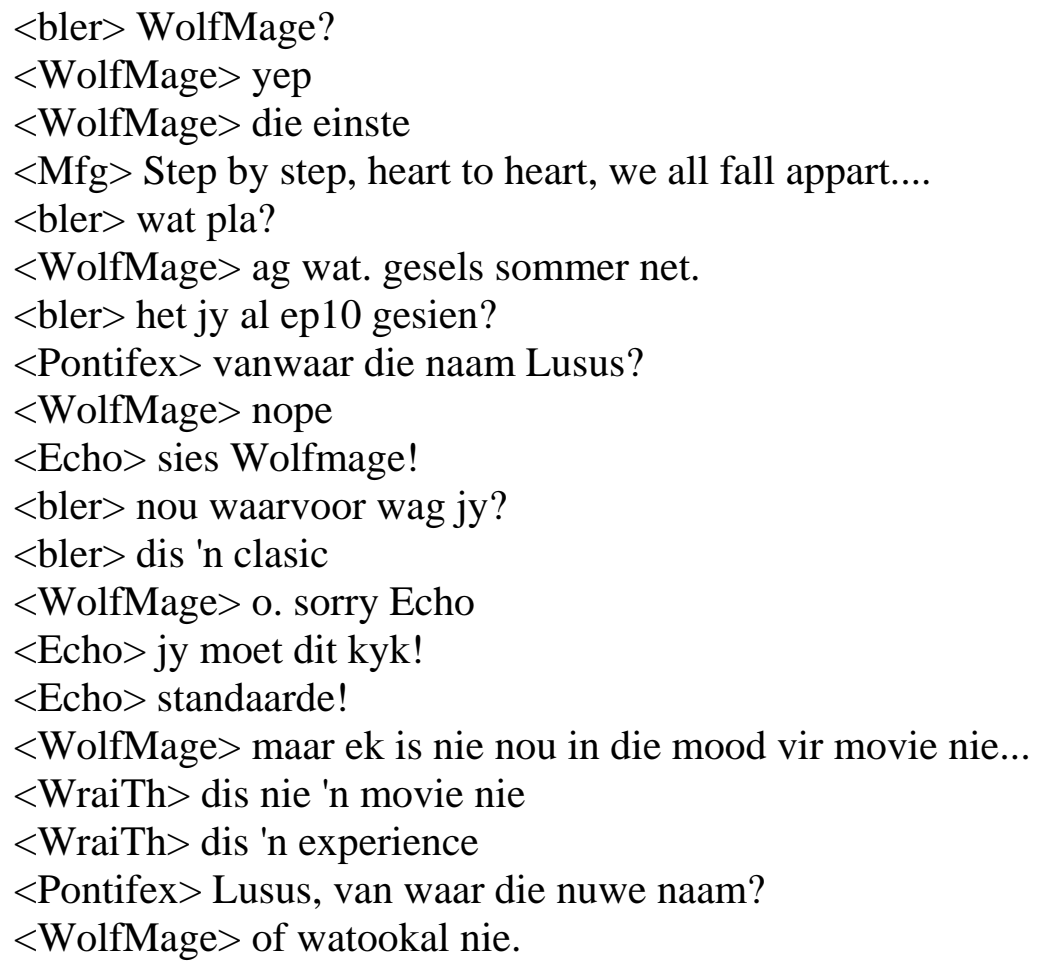


$<$ bler $>$ daar is 'n rerig nice deel in wat my baie geraak het

$<$ Pontifex $>$ grrr...

$<$ Echo $>$ ek is bly bler

* WolfMage sug

$<$ Mfg > Daar is 'n song: Die Fantastischen Vier - 03 - MfG

$<$ bler $>$ ek gaan die ep op cd sit sodat ek dit veraltyd kan hou.

$<$ Echo $>$ ek is bly ons kon iemand raak

$<$ Pontifex $>$ i like being ignored. it's very comforting to have only yourself to speak

to

* WolfMage wens julle almal 'n lekker nagrus toe.

$<$ Echo $>$ bler, die dvd is available binnekort

$<$ Mfg $>$ En ek wou nie my stats spoil in my huidige toestand nie. :P

$<$ Pontifex $>$ yay!... he speaks

$<$ WolfMage $>$ sorry Pontifex.

$<$ bler $>$ oooohhhh

$<$ Echo $>$ dan het jy die hele season 1 op een disc

$<$ BoRgQueeN $>$ Pontifex, ek wonder dieselfde as jy

It is interesting to note that this complexity can lead to breakdowns in communication. In the above extract, <bler $>$ and <WolfMage $>$ begin a conversation, in the middle of which $<$ Mfg $>$ inserts a line from a song for no apparent reason. $<$ Pontifex $>$ begins another strand of conversation by asking $<\mathrm{Mfg}>$ (a participant who previously chatted under the nick $<$ Lusus $>$ ) where his new nick comes from. As the exchange proceeds, <bler $>$ and $<$ Wolfmage $>$ continue their conversation, and $<$ Pontifex $>$ asks his question once again. He then becomes frustrated at what he interprets as $<\mathrm{Mfg}>$ ignoring him, even though $<\mathrm{Mfg}>$ has answered his question. It is because the conversation between <bler $>$, <WolfMage $>$ and <Echo> is happening simultaneously that <Pontifex $>$ misses <Mfg>'s response. Eventually, it is one of the other participants, $<$ WolfMage $>$, who ends up apologising to $<$ Pontifex $>$, while $<$ BoRgQueeN $>$ tries to mitigate the situation by indicating her own interest in the answer to <Pontifex>'s question. However, this confusion is not necessarily widespread. In general, experienced IRC users appear to have acquired a loose set of conventions that enable them to manage and follow the complex conversations that occur in IRC (Werry 1996:51).

\subsection{Addressivity}

A feature of IRC discourse that is a direct result of the discontinuity in exchange structures and the lack of turn-taking cues, such as gesture and gaze, which occur in face-to-face 
conversation, is addressivity (Werry 1996:52). A user will indicate the intended addressee by inserting that individual's nick at the start of an utterance, in order to avoid ambiguity. This feature is illustrated by the last utterance in the previous example and by examples (11)-(12) below. It was found that, although addressivity is present in the data, the absence of addressivity is far more common, indicating, perhaps, that the majority of conversations on Afrikaans IRC channels involve all the participants equally.

$<$ BirdWithoutWings > what about me? :( @ Data

$<$ Data_Hoare $>$ BirdWithoutWings, i have two hands and one mouth

(12) < die_skim> SLEEK : what are you waiting for $<$ sleek> for bunny steaks

\subsection{Phonological simulation}

A pervasive feature of communication on IRC is that of phonological simulation - the representation of spoken features in online communication (Palfreyman and al Khalil 2003). This is achieved through the creative use of spelling, punctuation and capitalisation. According to Werry $(1996: 48,56)$, these orthographic strategies are designed to compensate for the lack of prosodic and paralinguistic cues, and therefore make communication more "speech-like". However, according to Palfreyman and al Kahlil (2003), this fails to recognise the social significance of this way of writing. Phonological simulation is motivated by more than the need to make communication on IRC similar to spoken language; it is also "a result of social pressure to break conventional spelling rules and comply with IRC's nonconformist, hacker image" (Stevenson 2000). When we examine the data, it is clear that this phonological simulation also characterises the use of Afrikaans on IRC.

\subsubsection{Eccentric spelling}

One way to simulate speech through the written language is to use colloquial verbalisations and non-standard spellings. These phonetic spellings require initial conscious reading as the unfamiliarity with their shape prevents one from automatically recognising the words and

processing them (Stevenson 2000). The creative use of orthography enables users to mimic 
aspects of face-to-face conversation such as accent, intonation and emphasis. This feature is clearly visible in the Afrikaans data, as shown by examples (13)-(16) below. In each case, the standard spelling is inserted in square brackets after the item.

$$
<\text { segfault }>\text { wassas [what's up] }
$$

$<\operatorname{Maxx}>$ hugannit?

[hoe gaan dit]

$$
<\mathrm{p} 4 \mathrm{n}>\text { sjeers }
$$

[cheers]

$$
<\text { Asjas }>\text { seblieff }
$$

[asseblief]

In example (17) below, one of the participants, $<\mathrm{GeHeNnA}>$, produces an utterance that clearly reflects the perceived sound and flow of spoken Afrikaans. The use of the nonstandard Afrikaans contraction weeti, instead of the standard weet nie, as well as the dropping of the word final letters of maar and nie, achieve the intended effect.

(17) < GeHeNnA> ek weeti wat aangaan, ma my sms'e word ni ontvang deur sekere ander en ek kry ook ni sekeres ni

Another aspect of the use of eccentric spelling in Afrikaans on IRC is the use of reduplicated letters to represent drawn-out or expressive intonation (Werry 1996:57), as the following two examples illustrate:

$$
\text { <bler> jaja, dis 'n laaaannnggg storie }
$$

$$
<\text { segfault }>\text { raaaaaaaaaaaait }
$$

\subsubsection{Creative punctuation}

Another method used to create the effects of spoken language, evident in the Afrikaans data, is the use of punctuation. Ellipsis and hyphens are used to create pauses and to 
simulate the flow of speech. The disfluencies that characterise spoken language and that are evident in Afrikaans CMC have been discussed in Section 4.1. In the following two examples, we see how ellipsis is used to indicate the tempo of the conversation:

(20) <ryskorrel> borgqueen kannie chat nie...sy moet trivia :)

(21) <Delltree> Oh... impressive... Ek's nie popular genoeg om op 'n kommitee te wees nie

Multiple punctuation is one of the features that Danet (2001:18) identifies as characteristic of online writing. Although a few instances of this feature can be observed in the Afrikaans data, as examples (22)-(23) below illustrate, multiple punctuation is not widespread, and occurs more often in conjunction with other means of emphasis, such as capitalisation (see Section 4.4.3).

$<$ mugster $>$ halooooooeeeeeeha!!!

(23) < Predator> if u take away his average against zimbabwe and bangladesh his average is 13 !!!!!!!!!!!!!!!!!!!!!!

\subsubsection{Capitalisation}

The use of capitalisation and lower case in IRC communication can be characterised as non-standard. Capitalisation is almost never used for beginning sentences or for proper nouns; rather, the use of lower case only is the norm. This is not as notable in Afrikaans where the first person pronoun, $e k$, is not capitalised in the same way as the English first person pronoun, I. Capitalisation is rather used as a device to indicate emphasis, or to create the impression of shouting, as illustrated by examples (24)-(26).

$<$ Mantis> AMAL IS VODACOM!!!!!

<AEther> VAKANSIEEEEEEEEEEEE!!!!!!!!!!!!!!!!!!!!!!!!!!! 


\subsection{Abbreviation}

One of the overriding concerns in IRC communication is that of speed. As the medium of IRC is virtually synchronous, there is a need to make one's contribution as swiftly as possible. So too is the wish to simulate speech a contributing factor to the need for rapid contributions. Spoken language is much faster than written language, and so the aspects of speech that aid speed are replicated in IRC communication in order to save time. One way in which brevity is achieved is through heavy abbreviation. In the Afrikaans data, there are many examples of syntactically-reduced forms and the clipping of words. This feature ties in with the discussion of non-standard orthography (see Section 4.4.1). The example below is a clear illustration of how words are clipped and contracted, firstly, due to speed of writing considerations and, secondly, due to the desire to simulate aspects of spoken language. In the first line of the extract, we can see the deletion of the subject pronoun, motivated by the need for brevity, and made possible by the nature of the IRC system which automatically prefaces each line with the speaker's nick, reducing the possibility of confusion (Werry 1996:54).

(27) <Mantis> wetie hoekom hy nie meer dit hetie

$<$ BobTheBuilder $>$ hy's nie meer oppie...

$<$ viXen> mantis ekt 7h wakker geword, was gstraand tot laaat uit...vat net nog 'n break v nog so 'n uurtjie :P

$<$ viXen> whatevr

$<$ viXen $>$ jul dc freex is almal $\mathbf{d}$ selle

Other aspects of abbreviation that occur in IRC communication are acronyms and rebus writing (Werry 1996, Danet 2000). Acronyms, which are formed by stringing the initial letters of words in phrases together, are frequently found in English CMC. However, no evidence was found in the data of unique Afrikaans acronyms. The only evidence of the use of acronyms found in the data was the use of the common English acronym lol ("laugh out loud"). Rebus writing, which is the use of a single symbol to represent a word or syllable with a similar sound, such as $u$ for $y o u, c$ for see, and 2 for two, is also a pervasive feature 
of English CMC. Again, no evidence was found for the use of this feature in the Afrikaans IRC communication; it was only present when an utterance was written in English.

A feature of IRC communication that can also be viewed as a form of abbreviation is the use of emoticons, which are a typographical symbolisation of emotion (Stevenson 2000). The use of emoticons is widespread in Afrikaans on IRC. They function primarily as indicators of the intention of an utterance. Examples (28)-(30) show a number of frequent emoticons used, with their intended meaning in square brackets.

(28) <bler> niks maak jou so vrolik soos missing memory nie $<$ bler $>$;) [indicating sarcasm]

(29) <WildBerry $>$ ek het ook iets opgetel

$<$ WildBerry $>$ 'n verkoue

$<$ WildBerry $>$ :p [indicating disgust]

$<$ JessicaRabbit $>$ WildBerry beleef sy menopause die dat hy so hot flushes kry ; ${ }^{\sim}$ [indicating humour]

(30) <BoRgQueeN> ai, ek moet seker bietjie werk ook :-/ [indicating dissatisfaction]

\subsection{Graphic simulation of sound}

Werry (1996:58) points out that throughout IRC conversations there is an almost manic tendency to produce auditory and visual effects in writing. In order to achieve this, users attempt to graphically simulate linguistic and non-linguistic sounds, such as laughter, singing, snarls, barks, and various other noises. This feature is evident in the Afrikaans data, with the most frequent representation of sounds being written-out laughter, both normal and "evil" laughter, and vocalisations indicating thought or frustration, as examples (31)-(34) below illustrate.

$<$ BoRgQueeN $>$ hehe $<$ xact $>$ mwahahahahha 

$<$ WildBerry $>$ hhmmmMMMMmmmmmMMMMMmmmmmm $<$ BoRgQueeN $>$ aaaaaaargh

Other sounds are also graphically represented in the IRC conversations, such as the representation of a siren and of metal objects banging together in the following two examples.

<Lusus> Aaarrrooooraaaa!!!

$$
\begin{aligned}
& <\text { JessicaRabbit }>*_{\text {clang }}^{*} * \text { clang* } \\
& <\text { xact }>*_{\text {squish } *}^{*} \text { clang* }
\end{aligned}
$$

\subsection{Actions and gestures}

Werry's (1996:59) final category for the features of IRC communication is that of actions and gestures. We have already discussed how users on IRC attempt to reproduce the characteristics of spoken language. By using a set of codes and conventions, it is possible for users to symbolise the gestural qualities of face-to-face conversation with words and visual images. The description of physical actions is the most distinctive aspect of this feature. This is achieved with the IRC command /me followed by the action the user wishes to perform. This results in the utterance being preceded by an asterisk and appearing in the third person. The use of this command on IRC enables users to both symbolically enact an action and give a description of their current state:

(37) * WildBerry gaan maak sy water bottel vol

* WildBerry het n lekker husky stem van die verkoue ;p

(38) * Mfg takes a bow

* Mfg neuk vooroor.

(39) * bler grom vir Mfg 
In $\mathrm{DC}++$, however, this command does not function (one of the few differences between communication on IRC and on DC++). Users still make use of this command, however, although it does not have the same representation, as can be seen in examples (40)-(41).

$<$ Hawk $>$ /me dans in sy kamer rond $<$ vlooi $>$ /me gee NET vir pred huggles

It is also possible to describe actions without using the IRC command. In this case, users insert the utterance between two asterisks, in order to indicate its function as an action, as the following example illustrates.

$$
<\text { JessicaRabbit }>\text { *sug* }
$$

\subsection{Self correction}

A feature of the use of Afrikaans on IRC that does not appear to have been addressed in the literature to date is that of self correction. The correction of written utterances is not usually an observable phenomenon, as the editing process of most forms of writing is not visible. However, this is an observable feature of face-to-face conversations. In the Afrikaans data, there are many examples of users correcting previous utterances, as the examples below illustrate. In example (44), it is interesting to note how < JessicaRabbit> involves the other members of the conversation in helping her to correct her utterance.

(43) <bler> so lank dit my nie 'n arm en 'n been gaan koop nie. $<$ bler $>*$ kos

(44) * JessicaRabbit wurg xact met 'n barbeb wire $<$ JessicaRabbit> aarrggghhh spelfout! :/

$<$ JessicaRabbit> barbed met 'n "d" nè?

$<$ JessicaRabbit> my brein ontgaan my op die oomblik :/

* JessicaRabbit prod vir xact en WildBerry

$<$ JessicaRabbit $>$ ?

$<$ WildBerry $>$ ja "d" 


\subsection{Code switching and code mixing}

The last characteristic of Afrikaans on IRC to be discussed in this paper is that of code switching and code mixing. In the data examined, there was a fair amount of code switching, which is "the alternate use of two languages within the same utterance or during the same conversation" (Hoffmann 1991:110) and code mixing, which is the insertion of constituents from one language into utterances in the other, dominant, language (Hamers and Blanc 2000:260). Examples (45)-(46) illustrate code mixing in IRC communication, with the insertion of English words and phrases into the Afrikaans utterances. Example (47) illustrates code switching in IRC communication. In each case, there is a switch from one language, English, to the other language, Afrikaans. In the case of < gideon>'s utterance, he switches back into English.

(45) < Echo> die main theme is dieselfde as die background music van die dvd advert movie clip

(46) <WildBerry> ek het op n kol vir gamers hulle PCs opgestel (at a price) en getweak vir performance $; \mathrm{p}^{\sim}$

* Mfg takes a bow...

* Mfg neuk AMPER weer vooroor...

<gideon> But this is just sad... Ons klink soos geeks... Praat oor sex op 'n chatroom...

\section{How the mighty have fallen}

It is possible to distinguish between three types of code switching, according to the reason for the switch, namely conversational code switching, situational code switching and metaphorical code switching (Downes 1998:80-85). The above examples of code switching and code mixing can be characterised as conversational code switching, as the different languages are used for communicative effect, rather than for any identifiable social reason. Example (48) below is an illustration of situational code switching. The first speaker, $<$ Sultan $>$, is clearly not a first language speaker of Afrikaans. He communicates with $<\mathrm{p} 4 \mathrm{n}>$, the other participant in the conversation, in English, and $<\mathrm{p} 4 \mathrm{n}>$ responds using English as well. However, when a third participant joins the conversation and asks a 
question in Afrikaans, $<\mathrm{p} 4 \mathrm{n}>$ switches into Afrikaans to continue the conversation. It is clear that the reason for the code switch in this case is the change in interlocutors.

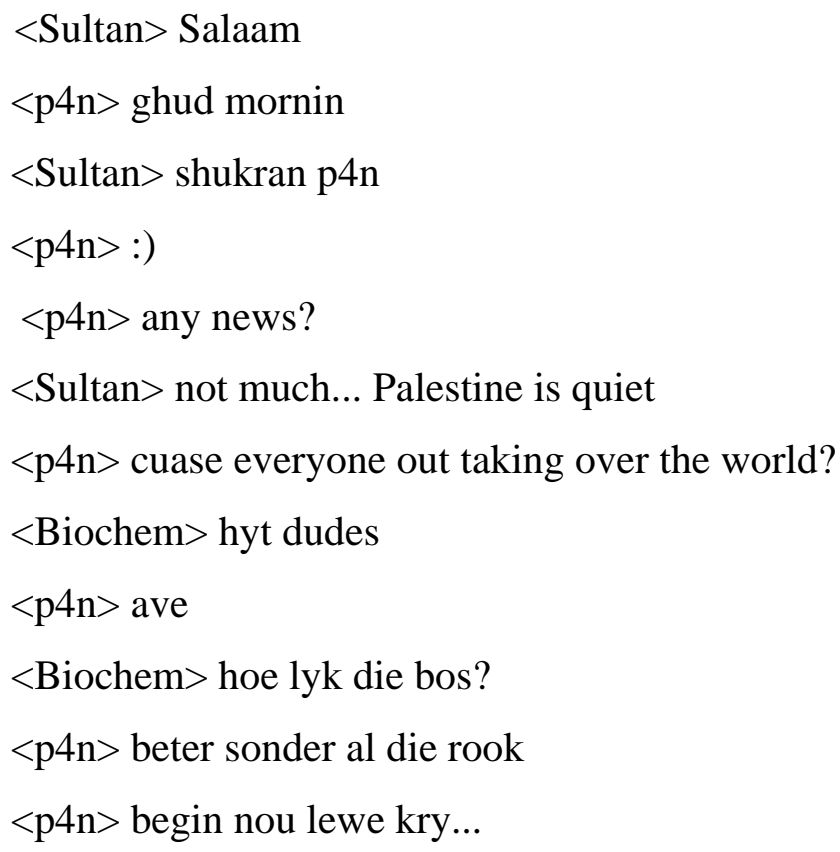

\section{Conclusion}

This paper has attempted to address the need for research into CMC in languages other than English. It has examined the linguistic and interactional characteristics of Afrikaans as used on IRC. The analysis of the data shows that Afrikaans CMC is characterised by the same discursive properties as those that characterise English CMC, such as the organisation of conversational sequences, and addressivity. The linguistic features of English CMC, such as phonological simulation (which includes the creative use of capitalisation, spelling and punctuation); abbreviation; graphic simulation of sounds; and the description of actions and gestures, also occur in the varieties of Afrikaans used in CMC; however, there are differences between the characteristics of Afrikaans and English as used on IRC. It is noted that more attention is paid to typographical errors than is expected, distinguishing Afrikaans CMC from typical interactions in English CMC. A further linguistic characteristic of interactions in Afrikaans on IRC is the prevalence of code mixing and code switching. 
It is noted that most of the features of Afrikaans CMC, such as phonological simulation and the graphic simulation of sounds, are a reaction to the absence of visual cues and other paralinguistic information on IRC, and an attempt to make the written conversation appear more like face-to-face conversation. However, it is important to point out that each of the options that a user has at his or her disposal requires a conscious, deliberate action (Kötter 2003:148). Unlike spoken discourse, where paralinguistic cues such as intonation, laughter and gestures are used almost subconsciously, in written CMC a person has to consciously encode all the feelings experienced and actions undertaken into written text if he or she wishes to share them with the other participants.

There is clearly room for further research into the characteristics and use of Afrikaans on the "multilingual" Internet. For instance, code switching and code mixing in bilingual and multilingual conversation, addressed briefly in this paper, is a major topic of research in sociolinguistics. Future research on code switching and code mixing in CMC could contribute a great deal to the field. 


\section{Notes}

1. See http://www.irchelp.org/irchelp/faq.html for a list of the basic IRC commands available and for more information on IRC and answers to questions on rules of conduct and etiquette on IRC.

2. The relevant aspects of the examples are marked in bold for ease of reference. The examples containing Afrikaans re-appear in the appendix, together with an English translation of the Afrikaans sections. 


\section{References}

Baron, N. 1998. Letters by phone or speech by other means: the linguistics of e-mail. Language and Communication 18: 133-170.

Baron, N. 2000. Alphabet to e-mail: how written English evolved and where it's heading. New York and London: Routledge.

Chafe, W.L. 1985. Linguistic differences produced by differences between speaking and writing. In D.R. Olson, N. Torrance, and A. Hildyard (eds.) Literacy, language and learning. Cambridge: Cambridge University Press. pp. 105-123.

Crystal, D. 2001. Language and the Internet. Cambridge: Cambridge University Press.

Danet, B. 2001. Cyberpl@y. Communicating online. New York and Oxford: Berg.

Danet, B. and S.C. Herring. 2003. Introduction: the multilingual Internet. Journal of Computer Mediated Communication 9(1). [Online]. Available at http://jcmc.indiana.edu/vol9/ issue1/intro.html (Accessed 24 January 2005).

Danet, B., L. Reudenberg-Wright, and Y. Rosenbaum-Tamari. 1997. "Hmmm...where's that smoke coming from?" Writing, play and performance on Internet Relay Chat. Journal of Computer Mediated Communication 2(4). [Online]. Available at http://jcmc.indiana.edu/ vol2/issue4/danet.html (Accessed 5 March 2005).

Downes, W. 1998. Language and society. $2^{\text {nd }}$ ed. Cambridge: Cambridge University Press.

Hamers, J.F. and M.H.A. Blanc. 2000. Bilinguality and bilingualism. $2^{\text {nd }}$ ed. Cambridge: Cambridge University Press.

Hård af Segerstad, Y. 2000. Swedish chat rooms. M/C: A Journal of Media and Culture 3(4). [Online]. Available at http://journal.media-culture.org.au/0008/swedish.php (Accessed 5 March 2005).

Herring, S.C. 2001. Computer-mediated discourse. In D. Tannen, D. Schiffrin, and H. Hamilton (eds.) Handbook of discourse analysis. Oxford: Blackwell. pp. 612-634.

Hoffman, C. 1991. An introduction to bilingualism. London: Longman.

Kötter, M. 2003. Negotiation of meaning and codeswitching in online tandems. Language Learning and Technology 7(2): 145-172.

Murray, D.E. 1988. The context of oral and written language: a framework for mode and medium switching. Language in Society 17: 351-373. 
Newhagen, J.E. and S. Rafaeli. 1996. Why communication researchers should study the Internet: a dialogue. Journal of Computer-Mediated Communication 1(4). [Online]. Available at http://jcmc.indiana.edu/vol1/issue4/rafaeli.html (Accessed 5 March 2005).

Nishimura, Y. 2003. Linguistic innovations and interactional features of casual online communication in Japanese. Journal of Computer-Mediated Communication 9(1). [Online]. Available at http://jcmc.indiana.edu/vol9/issue1/nishimura.html (Accessed 5 March 2005).

Palfreyman, D. and M. al Khalil. 2003. "A funky language for teenzz to use": representing Gulf Arabic in Instant Messaging. Journal of Computer-Mediated Communication 9(1). [Online]. Available at http://jcmc.indiana.edu/vol9/issue1/nishimura.html (Accessed 21 February 2005).

Paolillo, J. 1999. The virtual speech community: social network and language variation on IRC. Journal of Computer-Mediated Communication 4(4). [Online]. Available at http://www. ascusc.org/jcmc/vol4/issue4/paolillo.html (Accessed 9 January 2004).

Reid, E.M. 1991. Electropolis: communication and community on Internet Relay Chat. Unpublished honours thesis, University of Melbourne, Australia. [Online]. Available at http://www.irchelp.org/irchelp/misc/electropolis.html (Accessed 9 January 2004).

Rintel, E.S., J. Mulholland, and J. Pittam. 2001. First things first: Internet Relay Chat openings. Journal of Computer-Mediated Communication 6(3). [Online]. Available at http://jcmc.indiana.edu/vol6/issue3/rintel.html (Accessed 24 January 2005).

Rintel, E.S. and J. Pittam. 1997. Strangers in a strange land. Interaction management on Internet Relay Chat. Human Communication Research 23(4): 507-534.

Stevenson, J. 2000. The language of Internet chat rooms. [Online]. Available at http://www.netting-it.com/Units/IRC.htm (Accessed 9 January 2004).

Werry, C.C. 1996. Linguistic and interactional features of Internet Relay Chat. In S.C. Herring (ed.) Computer-mediated communication. Linguistic, social and crosscultural perspectives. Amsterdam: John Benjamins Publishing Company. pp. 47-63. 


\section{Appendix: Paraphrases/translations of Afrikaans sections of examples}

\section{Involvement in IRC communication}

(1)

$<$ bler> niks maak jou so vrolik soos missing memory nie $<$ bler $>$;)

$<$ bler $>$ maar jy sal dit nog agter kom.

$<$ bler $>$ o wag, ek het vergeet, jy's mos een van daai slim ing ouens

(2)

$<$ bler $>$ hmm

$<$ bler $>$ hoekom nie segfault?

Use of flow-monitoring devices in IRC communication

(3)

$<$ JessicaRabbit> ok WildBerry, my pc se private details nou almal neergeskryf ;p

$<$ xact $>$ as opposed to, say, public details?

(4)

$<$ JessicaRabbit> wel sy het omtrent 10gig spasie en dis hoeveel my musiek is

$<$ JessicaRabbit> ja, ek sal net eers seker maak sy't als

opgekry

$<$ WildBerry $>$ right (nothing makes one happier than missing memory)

(but you will still learn that)

(oh wait, I forgot, you're one of those clever engineering guys)

(why not segfault?) (ok WildBerry, all my pc's private details are now written down)

(well she has about 10 gigs of space and that's how much my music is) (yes, I'll just first make sure she got everything on)

\section{Disfluencies in IRC Communication}

(5)

$<$ xact $>$ of is die afwesigheid juis weens klasse, dink julle?

$<$ WildBerry $>$ um

$<$ WildBerry $>$ komitee sou ek dink

(or is it absence because of classes, do you think?)

(committee I would think)

(6)

$<$ WildBerry $>$ hmmm ek begin beter voel.. $\quad$ (I'm beginning to feel better) this is good 
(7)

$<$ Delltree $>$ So... Voor ons nou te serious en (So... Before we get too serious and deep diep raak... $<$ Delltree $>$ Oh ok...

$<$ Delltree $>$ Flaws

$<$ Delltree $>$ Laat ek dink

$<$ Delltree $>$ Ek trust nie maklik ander nie... now)

(Let me think)

(I don't easily trust others)

\section{Short, independent idea units in IRC communication}

(8)

$<$ Agnus $>$ ek eet choclate

$<$ Data_Hoare $>$ lekker

$<$ Data_Hoare $>$ ek is bly

$<$ Data_Hoare $>$ chocolate is mos jou kos

(9)

$<\mathrm{Mfg}>\mathrm{Ek}$ is sterkteleer ook darem net op my gat deur...

$<$ BoRgQueeN $>$ ek ook

$<$ BoRgQueeN $>$ die vak haunt my

$<$ BoRgQueeN $>$ ek kannie ontslae daarvan

raak nie

$<$ BoRgQueeN $>$ dis al wat ek demi
(I eat chocolate)

(nice)

(I am glad)

(chocolate is your food)
(I passed "strength of materials" also just by the skin of my teeth)

(me too)

(the subject haunts me)

(I cannot get rid of it)

(It's all that I tutor)

\section{Exchange structure in IRC communication}

(10)

$<$ bler $>$ WolfMage?

$<$ WolfMage $>$ yep

$<$ WolfMage $>$ die einste

$<\mathrm{Mfg}>$ Step by step, heart to heart, we all fall appart....

$<$ bler $>$ wat pla?

$<$ WolfMage $>$ ag wat. gesels sommer net.

$<$ bler $>$ het jy al ep10 gesien?

$<$ Pontifex $>$ vanwaar die naam Lusus?

$<$ WolfMage $>$ nope

$<$ Echo $>$ sies Wolfmage!

$<$ bler $>$ nou waarvoor wag jy?

$<$ bler $>$ dis 'n clasic

$<$ WolfMage $>$ o. sorry Echo

$<$ Echo $>$ jy moet dit kyk!

$<$ Echo $>$ standaarde!

$<$ WolfMage $>$ maar ek is nie nou in die mood vir movie nie...

(the same)

(what's bothering you?)

(oh well. just talking)

(have you seen episode 10 yet?)

(where's the name from Lusus?)

(now what are you waiting for?)

(it's a classic)

(you must watch it)

(standards!)

(but I'm not in the mood for a movie now) 
$<$ WraiTh $>$ dis nie 'n movie nie

$<$ WraiTh $>$ dis 'n experience

$<$ Pontifex $>$ Lusus, van waar die nuwe naam?

$<$ WolfMage $>$ of watookal nie.

$<$ bler $>$ daar is 'n rerig nice deel in wat my

baie geraak het

$<$ Pontifex $>$ grrr...

$<$ Echo $>$ ek is bly bler

* WolfMage sug

$<$ Mfg $>$ Daar is 'n song: Die Fantastischen

Vier - 03 - MfG

$<$ bler> ek gaan die ep op cd sit sodat ek dit

veraltyd kan hou.

$<$ Echo $>$ ek is bly ons kon iemand raak

$<$ Pontifex $>$ i like being ignored. it's very comforting to have only yourself to speak to

* WolfMage wens julle almal 'n lekker nagrus toe.

$<$ Echo $>$ bler, die dvd is available binnekort $<$ Mfg $>$ En ek wou nie my stats spoil in my huidige toestand nie. :P

$<$ Pontifex $>$ yay!... he speaks

$<$ WolfMage $>$ sorry Pontifex.

$<$ bler $>$ oooohhhh

$<$ Echo $>$ dan het jy die hele season 1 op een

disc

$<$ BoRgQueeN $>$ Pontifex, ek wonder dieselfde as jy

\section{Phonetic spelling in IRC communication}

(14)

$<$ Maxx $>$ hugannit? [hoe gaan dit]

(16)

$<$ Asjas $>$ seblieff [asseblief] (it's not a movie)

(it's an experience)

(Lusus, where's the new name from?)

(or whatever not)

(there is a really nice part that really touched me)

(I am glad bler)

(*WolfMage sighs)

(there is a song:)

(I'm going to put the episode on cd so that I can keep it forever)

(I am glad we could touch someone)

(*WolfMage wishes you all a nice night's sleep)

(bler, the dvd will be available shortly)

(And I didn't want to spoil my statistics in my present condition)

(then you have the whole season 1 on one disc)

(Pontifax, I wonder the same thing as you)

\section{Non-standard contractions in Afrikaans on IRC}

(17)

$<$ GeHeNnA $>$ ek weeti wat aangaan, ma my sms'e word ni ontvang deur sekere ander en ek kry ook ni sekeres ni
(I don't know what's going on, but my sms's are not received by certain others and I also don't receive certain ones either) 


\section{Reduplicated letters in IRC communication}

(18)

<bler> jaja, dis 'n laaaannnggg storie

(yes yes, it's a long story)

(19)

<segfault> raaaaaaaaaaaait

(right)

\section{Ellipsis in IRC communication}

(20)

<ryskorrel> borgqueen kannie chat nie...sy moet trivia :)

(borgqueen cannot chat... she has to trivia)

$<$ Delltree $>$ Oh... impressive... Ek's nie popular genoeg om op 'n kommitee te wees nie

(I'm not popular enough to be on a committee)

\section{Capitalization in IRC communication}

(24)

$<$ Mantis> AMAL IS VODACOM!!!!!

(everyone is Vodacom)

(25)

<AEther> VAKANSIEEEEEEEEEEEE!!!!!!!!!!!!!!!!!!!!!!!!!!! (holiday)

$<$ die_skim> WIE IS IN BEHEER VAN HIERDIE

SIRKUS!?!?!?

(who is in control of this circus)

\section{Abbreviation in IRC communication}

(27)

$<$ Mantis $>$ wetie hoekom hy nie meer dit hetie

$<$ BobTheBuilder $>$ hy's nie meer oppie...

$<$ viXen> mantis ekt 7h wakker geword, was gstraand

tot laaat uit...vat net nog 'n break v nog so 'n uurtjie :P

$<$ viXen $>$ whatevr

$<$ viXen $>$ jul dc freex is almal $\mathbf{d}$ selle

\section{Emoticons in IRC communciation}

(29)

$<$ WildBerry $>$ ek het ook iets opgetel (don't know why he doesn't have it anymore)

(he's not on anymore)

(mantis I woke up at 7h, was out until late last night...just taking a break for another hour or so)

you dc freaks are all the same

$<$ WildBerry > 'n verkoue 
$<$ WildBerry $>$ :p

$<$ JessicaRabbit> WildBerry beleef sy menopause die dat hy so hot flushes kry ; ${ }^{\sim}$

(30)

$<$ BoRgQueeN> ai, ek moet seker bietjie werk ook :-/

(I also picked up something)

\section{Symbolic enactment of actions in IRC communication}

(37)

* WildBerry gaan maak sy water bottel vol

* WildBerry het n lekker husky stem van die verkoue ;p

(38)

* Mfg takes a bow

* Mfg neuk vooroor.

(39)

* bler grom vir Mfg (a cold)

(WildBerry is experiencing his menopause so, that he gets hot flushes)

oh, I should probably work a little too)

(*Mfg falls over forwards)

(*bler growls at Mfg)

\section{Symbolic enactment of actions in DC++}

(40)

$<$ Hawk $>$ /me dans in sy kamer rond

(/me dances round in his room)

(41)

$<$ vlooi $>$ /me gee NET vir pred huggles

(/me ONLY gives huggles to pred)

Use of asterisks in the enactment of actions in IRC communication

(42)

$<$ JessicaRabbit $>$ *sug*

$\left({ }^{*} \operatorname{sigh} *\right)$

\section{Self correction in IRC communication}

(43)

$<$ bler> so lank dit my nie 'n arm en 'n been gaan koop nie.

$<$ bler $>*$ kos

(44)

* JessicaRabbit wurg xact met 'n barbeb wire (so long as it isn't going to "buy" me an arm and a leg)

(*cost) 
$<$ JessicaRabbit> aarrggghhh spelfout! :/

$<$ JessicaRabbit> barbed met 'n "d" nè?

$<$ JessicaRabbit> my brein ontgaan my op die oomblik :/

* JessicaRabbit prod vir xact en WildBerry

$<$ JessicaRabbit $>$ ?

$<$ WildBerry $>$ ja "d"

(*JessicaRabbit throttles xact with barbed wire)

\section{Code mixing in IRC communication}

(45)

$<$ Echo $>$ die main theme is dieselfde as die background music van die dvd advert movie clip

(46)

$<$ WildBerry $>$ ek het op n kol vir gamers hulle PCs

opgestel (at a price) en getweak vir performance ; $\sim$

\section{Code switching in IRC communication}

(47)

* Mfg takes a bow...

* Mfg neuk AMPER weer vooroor...

<gideon> But this is just sad... Ons klink soos geeks...

Praat oor sex op 'n chatroom... How the mighty have fallen

\section{Situational code switching in IRC communication}

(48)

$<$ Sultan $>$ Salaam

$<\mathrm{p} 4 \mathrm{n}>$ ghud mornin

$<$ Sultan $>$ shukran $\mathrm{p} 4 \mathrm{n}$

$<\mathrm{p} 4 \mathrm{n}>$ :)

$<$ p4n $>$ any news?

$<$ Sultan $>$ not much... Palestine is quiet

$<$ p4n $>$ cuase everyone out taking over the world?

$<$ Biochem $>$ hyt dudes

$<$ p4n $>$ ave

$<$ Biochem $>$ hoe lyk die bos?

$<\mathrm{p} 4 \mathrm{n}>$ beter sonder al die rook

$<\mathrm{p} 4 \mathrm{n}>$ begin nou lewe kry... (spelling mistake)

(barbed with a "d" right?)

(my brain escapes me at the

moment)

*JessicaRabbit prods xact and

Wildberry)

(yes "d")

(the main theme is the same as the background music from the dvd movie advert clip)

(at one point I set up PCs for gamers (at a price) and tweaked them for performance)

(* Mfg ALMOST falls over again) (... We sound like geeks... Talk about sex in a chatroom...) (how is "Stellenbosch" looking?)

(better without all the smoke)

(starting to get life...) 
